\title{
The Implementation of Hypnobirthing Effect on Pain Relief in the Intrapartum Period at Klinik Pratama Rakyat Hospital Makassar
}

\author{
Een Kurnaesih ${ }^{1}$, Nia Karuniawati ${ }^{2}$, Siti Fatimah Azahrah ${ }^{3}$, Sundari², Alfina Baharuddin ${ }^{4}$ \\ ${ }^{1}$ Associate Professor, Department of Midwifery Faculty of Publik Healtth, Universitas Muslim of Indonesia, \\ ${ }^{2}$ Lecturer Department of Midwifery Faculty of Publik Healtth, University Muslim of Indonesia, ${ }^{3}$ Practitioners \\ Psikolog Kuningan Jawa Barat, ${ }^{4}$ Lecturer DepartementEnvironmetl of Public Health,University Muslim of \\ Indoensia
}

\begin{abstract}
The pain of childbirth is one of the factors that causes a mother to become anxious even to the point of despair, so mothers tend to choose a shortcut to speed up their childbirth, either by requesting an operation, or by taking a remedy to relieve the pain by taking an analgesic drug, whereas pain caused during childbirth is pathological because of the effects of changing uterus that creates pathways or openings.

The type of research is experimental quantitative research using Quasi Experimental method, namely experimental design with the observation design (measurement pain intensity) before and after treatment (Hypnobirthing treatment) which consists of the two group, namely the intervention group (Hypnobiththing) and the control group. Sampling was taken from June to August 2020 with the number of samplings intervention group (Hypnobiththing) as many as 20 respondents and the control group as 20 respondents. Data analysis method uses Univariate and Bivariate with t-test using SPSS Computer Program.

The results were obtained with the average of pain intensity in childbirth after being given Hypnobiththinghad a decrease in pain while the control class was upgraded. The results of statistical test are presented $\rho$ valua by 0.000 at the mistaken rate of $(\alpha) 5 \%$ or 0,05 (trust $95 \%$ ) so value is $\rho<\alpha$. The data indicated that there was a significant (apparent) of Hypnobiththingtreatment in childbirth relief. The conclusion of this research was that there was a significant Hypnobiththing effect on the treatment of childbirth at KlinikPratama Rakyat Hospital. That was expected for midwife duty at KlinikPratama Rakyat Hospital to adopt the method of Hypnobirthing to assist the mothers with normal childbirth.
\end{abstract}

Keyword: Pain, Normal Childbirth, Intrapartum, Hypnobirthing.

\section{Introduction}

The delivery process is a series of events that begins with the expulsion of the baby at term or near term, accompanied by removal of the placenta and fetal membranes from the birth canal. Problems that occur in

\footnotetext{
Corresponding Author:

Een Kurnaesih

Associate Professor, Department of Midwifery Faculty of Publik Healtth, Universitas Muslim of Indonesia e-mail: een.kurnaesih@umi.ac.id
}

the process of childbearing often have an impact on the death of both mother and fetus. The Maternal Mortality Rate is an indicator to see the degree of women's welfare and the target set in the Millennium Development Goals (MDGs) development goal 5, namely improving maternal health, which targets to be achieved by 2015 . The number of maternal deaths or 102/100,000 births life, therefore efforts to achieve these targets still require commitment and continuous hard effort ${ }^{1,2,3,4}$.

In the process of childbirth, of course, many things happen to the mother's body and to the fetus's body, one of which happens during childbirth is the pain that is felt 
by the mother, this is a normal or natural occurrence but many mothers do not understand that pain is good during childbirth, this is due to changes in the body, especially in the uterus, due to the influence of hormonal work that occurs during childbirth. There are many things that can be done by mothers to cope with feelings of pain during childbirth, including by adjusting the breathing patterns that are often taught during ANC but recently there are relaxation method that can be done by mothers to overcome pain, one of which is "Hypnobrirthing"5,6,7

This childbirth relaxation method called "Hypnobirthing" was developed by a midwife named Lanny Kuswandi through Fr. Jacson in Australia who made her realize that women are very special human beings and in Indonesia this method began to spread. Hypnobirthing is a therapeutic method that uses hypnosis as a means to reach the client's subconscious mind, so that the client can be directed to thoughts that are guided by the person who hypnotized them, so that the pain felt by the client can be channeled through a pleasant imagination and will reduce feelings pain that is being experienced. Pain during the intranatal period/ delivery period is physiological pain or normal pain because the pain felt by the mother is pain caused by widening thebirth canal or cervix, this is very necessary in the delivery process $8,9,10,11$

\section{Material and Method}

The research design was a quasi experiment with a pretest design with a control class. In this design, the research was conducted $2 x$, namely before the experiment (pretest) and after the experiment (postest). The sample in this study were 40 people, 20 intervention groups and 20 control groups. In the experimental group, a pre-test was carried out, then hypnotherapy was carried out then a post-test was carried out. Whereas in the control class only IEC was given to overcome labor pain without being given hypnotherapy and carried out a post tes

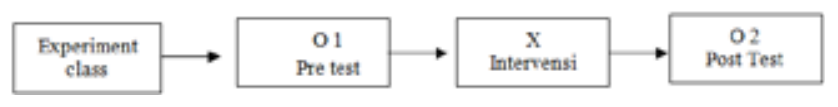

Information:

O 1: Measurement of labor pain before hypnotherapy

$\mathrm{X}$ : Hypnotherapy measures to reduce labor pain

O 2: Measurement of labor pain after hypnotherapy

\section{Result}

Table 1: Distribution of Respondents based on Mother's Gravid Intranatal with Normal Delivery

\begin{tabular}{|l|c|c|c|c|c|c|}
\hline \multirow{2}{*}{ Mother gravid } & \multicolumn{2}{|c|}{ Class Intervensi (Hyonobirthing) } & \multicolumn{2}{|c|}{ Control class } & \multicolumn{2}{|c|}{ Total } \\
\cline { 2 - 7 } & $\mathbf{n}$ & $\mathbf{\%}$ & $\mathbf{n}$ & $\mathbf{\%}$ & $\mathbf{n}$ & $\mathbf{\%}$ \\
\hline Multi & 15 & 75,0 & 12 & 60,0 & 27 & 67,5 \\
\hline Primi & 5 & 25,0 & 8 & 40,0 & 13 & 32,5 \\
\hline Total & $\mathbf{2 0}$ & $\mathbf{1 0 0} \%$ & $\mathbf{2 0}$ & $\mathbf{1 0 0 \%}$ & $\mathbf{4 0}$ & $\mathbf{1 0 0 \%}$ \\
\hline
\end{tabular}

Based on table 1 the intervention group who had a birth history of more than one birth (Multi) were 15 people $(75 \%)$ and the control group was 12 people
$(60 \%)$ and for mothers who had a first-time history of labor (Primi) as many as 5 people $(25.0 \%)$ and the control group as many as $8(40 \%)$.

Table 2: Distribution of Respondents Based on the Level of Pain Experienced by Pretest Intrapartum Mothers in the Respondent Group

\begin{tabular}{|c|c|c|c|c|c|}
\hline & & & \multicolumn{2}{|c|}{ Group responden } & \multirow{2}{*}{ Total } \\
\hline & & & Intervention & Control & \\
\hline \multirow{4}{*}{ Pre test } & \multirow{2}{*}{ Moderate Pain } & Count & 6 & 1 & 7 \\
\hline & & Group responden & $30,0 \%$ & $5,0 \%$ & $17,5 \%$ \\
\hline & \multirow{2}{*}{ Severe Pain } & Count & 14 & 19 & 33 \\
\hline & & Group responden & $70,0 \%$ & $95,0 \%$ & $82,5 \%$ \\
\hline \multirow{2}{*}{\multicolumn{2}{|c|}{ Total }} & Count & 20 & 20 & 40 \\
\hline & & Group responden & $100,0 \%$ & $100,0 \%$ & $100,0 \%$ \\
\hline
\end{tabular}


Based on table 2, the results of the analysis of the level of pain before the intervention were carried out on the intervention group and the control group as many as 40 groups, who experienced moderate pain levels for the intervention group as many as 6 people $(30 \%)$ and the control group I people (5.0\%)), while the group of mothers who experienced severe illness level were 14 people $(70 \%)$ and from the control group were 19 people (95.0\%).

Table 3: Distribution of Respondents Based on the Level of Pain Experienced by the MotherIntrapartum Prostest Respondent Group

\begin{tabular}{|l|l|l|c|c|c|}
\hline \multicolumn{2}{|c|}{} & Intervention & Control & \\
\hline \multirow{3}{*}{ Post test } & \multirow{2}{*}{ Moderate pain } & Count & 12 & 4 & 16 \\
\cline { 3 - 6 } & \multirow{3}{*}{ Severe pain } & Group responden & $60 \%$ & $20 \%$ & $40 \%$ \\
\hline \multirow{3}{*}{ Total } & Count & 8 & 16 & 24 \\
\cline { 2 - 6 } & & Group responden & $40 \%$ & $80 \%$ & $60 \%$ \\
\hline
\end{tabular}

Based on table 3, the results of the analysis of the level of pain after the intervention were carried out. The intervention was carried out on the intervention group and the control group as many as 40 groups, who experienced moderate pain levels for the intervention group as many as 12 people $(60 \%)$ and the control group 4 people $(20 \%)$, while the group of mothers who experienced severe illness level were 8 people $(40 \%)$ and from the control group were 16 people $(80.0 \%)$.

Table 4: Results of Normality Test for the Intervention Group (Hypnobirthing) and the Control Group

\begin{tabular}{|c|c|c|c|c|c|c|c|}
\hline \multirow{3}{*}{ Variabel } & \multicolumn{6}{|c|}{ Kelompok } & \multirow{3}{*}{$\begin{array}{l}\text { Level of } \\
\text { Significant }\end{array}$} \\
\hline & \multicolumn{3}{|c|}{ Intervensi (Hypnobirthing) } & \multicolumn{3}{|c|}{ Kontrol (Pemberian elusan) } & \\
\hline & Pre test & Post Test & Ket. & Pre test & Post Test & Ket. & \\
\hline Sig. (2-tailed) & 0,168 & 0,147 & Normal & 0,164 & 0,505 & Normal & 0,05 \\
\hline
\end{tabular}

Based on table 4 above, the results of the normality test using the one sample method above show that the sig. (2-tailed) $>$ level of significance $=0.05$ for both the intervention group and the control group, before and after the pre and post test.

Table 5: Results of T-Test Pre and Post Hypnoberting Intervention Group and the Control Group on pain management intrapartum at the hospital. Primary People's Clinic

\begin{tabular}{|c|c|c|c|c|c|}
\hline \multirow{2}{*}{ Group } & \multirow{2}{*}{$\mathbf{n}$} & \multicolumn{2}{|c|}{ Intensitas Nyeri (Mea+ SD) } & \multirow{2}{*}{$\mathbf{t}$} & \multirow{2}{*}{$\mathbf{p}$} \\
\hline & & Mean & Perbedaan & & \\
\hline \multicolumn{6}{|l|}{ Intervensi } \\
\hline (Hypnobirthing) Pre Test & 20 & 7,25 & 1,118 & 4,723 & 0,000 \\
\hline Post test & & 6,35 & 875 & & \\
\hline $\begin{array}{l}\text { Control } \\
\text { Pre Test }\end{array}$ & 20 & 8,00 & 858 & 2,979 & 0,008 \\
\hline Post test & & 7,45 & 1,146 & & \\
\hline
\end{tabular}




\section{Discussion}

The pain experienced by the mother during childbirth is due to changes in the physiology of the birth canal, where the uterus undergoes changes that occur in its muscles, especially the cervical area, which was originally thickened at the bottom of the cervix to become thin or begins to open, the muscles of the uterus, namely the upper and lower segments of the uterus are quite clear but with the effect of the contraction, the corvus and the service eventually change, namely the opening of the cervix which causes pain. The literature that supports this theory is the opinion of that labor pain is caused by the process of cervical dilation, uterine ischemia and stretching of the lower uterine segment and compression of the nerves in the cervix ${ }^{12,13,14}$

That pain depends on the work and the large and small nerves that are in the root of the dorsal ganglion. The stimulation of the large nerves will increase the mechanism of the activity of the substance gelatinosa which results in the closing of the door of the mechanism so that $\mathrm{T}$ cell activity is inhibited and causes the delivery of stimuli to be obstructed. Stimulation of small fibers will inhibit the activity of the substance gelatinosa and open the door to the mechanism, thereby stimulating $\mathrm{T}$ cell activity which in turn will deliver pain stimuli ${ }^{15,16}$,

In this study, the pain intensity of the respondents varied both in the intervention group with hypnobirthing and in the contral group that was given counseling, meaning that hypnobirthing was not done. Based on table 5.1 above, in this study before hypnobirthing was carried out, respondents who experienced moderate pain and severe pain were aged respondents, it was found that respondents with age $<20$ years were the intervention group, namely $2(10 \%)$ respondents while the control group was $0(0 \%)$ respondents with $20-30$ years of age in the Intervention group were 17 people $(85.0 \%)$ and the contral group were 20 people $(100 \%)$ and from the age group over 30 years the intervention group was 1 person $(2.5, \%)$. produced in Magfiroh's (2012) research in Adam and Umboh (2015) that the age of mothers who are $<25$ years old feels more severe pain than those aged 25-35 years. This is because a young person does not have enough experience with labor and pain, so they perceive pain to be heavier than older people. In addition, young people have a more intense pain sensory than mothers who have an older age. Youth tends to be associated with an unstable psychological condition that triggers fear and anxiety so that the pain you feel is getting stronger. Age is also used as a factor in determining tolerance to pain, $5,9,12,17$

The hypnobirthing method is an attempt to naturally instill positive thoughts or give psychological suggestions or subconscious thoughts during childbirth and preparation for labor based on the belief that every woman has the potential to undergo a normal, calm and comfortable birth process. The basis of hypnosis is the use of our ability to directly access the subconscious. Usually we are only aware of the thoughts that are in our conscious mind. We are consciously focused. to something in front of our eyes, we consciously speak and say words, or consciously we try to remember what we have done. But when doing these things, the conscious mind collaborates with the subconscious, our thoughts are carried or directed by a thought guide who performs Hypnosis in women who experience pain when facing childbirth by diverting thoughts (Kartasis) until they want to follow the commands direct it ${ }^{8,9,11,15}$.

Measurement of pain intensity in labor begins during the active period, namely starting the IV opening and is assigned as a pre test. Hypnobirthing treatment was carried out at the VII opening and every time the mother felt pain until the VIII opening and was determined as a post test. For the control group the pain scale was measured before and after the mother was given counseling/IEC ${ }^{8,11,14}$.

The hope of the Mother of Surakarta, that the majority of maternal pain levels before being given hypnobirthing (pretest) were severe pain as much as $70.0 \%$ and after being given hypnobirthing (post test) the level of maternal pain was moderate pain as much as $90 \%$. Test results with. Based on the explanation above, it can be concluded that the use of the hypnobirthing method can reduce the intensity of pain during labor ${ }^{18,19}$. There is a decrease in labor pain after hypnobirthing is done because this method brings respondents to integrate with the natural body movements and rhythms during childbirth, allowing the body and mind to work, Wilcoxon obtained a value of $\rho$ value $=0,000$.

\section{Conclution}

Hypnobirthing techniques can minimize labor pain because with hypnobirthing, mothers are required to achieve a very relaxed and comfortable condition during labor. The influence of the hynobirthing method on pain management during childbirth is because this method teaches natural relaxation techniques, so that the body 
can work with all nerves in harmony and with penu cooperation.

Source of Funding: Self-funding

Conflict of Interest: None of the authors has competing interests

Ethical Clearance: Taken from Comitee ethical ClearenceUniversitas Muslim of Indonesia Makassar

\section{References}

1. Adam, J., Umboh, J. M. L. Hubungan antara Usia, Paritas, dan Pendampingan Suami dengan Intensitas Nyeri persalinan Kala I Fase Aktif Deselarasi di Ruang Bersalin RSUD Prof. Dr. H. Aloei Saboe Kota Gorontalo.Artikel Penelitian, Jikmu, Vol. 5, No. 2a. 2015.

2. Anonim, Workbook Pelatihan Pelatihan Basic hypnosis dan hypnobirthing. CVC Klinik; Jakarta. 2010.

3. Ferial, E. W. Biologi Reproduksi. Ciracas, Jakarta: Erlangga, 2013.

4. Harahap, D. Pengaruh Teknik Relaksasi Hipnosis Diri terhadap Tingkat Nyeri dan Lama Persalinan Ibu Primipara di RS Ananda, Bekasi. Tesis. Fak. Ilmu Keperawatan. Universitas Indonesia. 2009.

5. Hidayat, A. A., Metode Penelitian Kebidanan Teknik Analisa Data.Jakarta: Salemba Medika. 2009.

6. Ida Widiawati.. Melahirkan Nyaman dan Cepat dengan Hypnobirthing. J. Ilmiah Ilmu Kesehatan, Vol. 7, No. 1, Hal: 45 - 52.2019.

7. Intan Kumala P. Pengaruh Hypnobirthing Terhadap Nyeri Persalinan Pada Ibu Inpartu Kala I Fase Aktif di Klinik Eka Sri Wahyuni Dan Kilinik Pratama Tanjung Tahun Skripsi. Politeknik Kesehatan Kemenkes Medan Jurusan Kebidanan Prodi D-IV2017.

8. Moh. Judha, Sudarti, Afroh F. Teori Pengukuran Nyeri dan Nyeri Persalinan disertai contoh Askep. Yogyakarta: Nuha Medika.2012
9. Kiblat Muslimah.Hipnosis: Mengupas Tren Hypnobirthing. https://kiblatmuslimah.com/ hypnosis - bag-2-selesai-mengupas-trenhypnobirthing.

10. Kuswandi. Kehamilan Persalinan dengan Hypnobirthing. PT. Bhuana Ilmu.2020 Populer Kelompok Gramedia; Jakarta. 2011.

11. Lestari Puji A., Arista A. P., Kuminah.. Efektifitas Relaksasi Hypnoberthing terhadap Penurunan tingkat Nyeri dan Kestabilan Tekanan Darah pada Persalinan kala I. J. Kebidanan, Vol. 11, No. 01. 2019.

12. Bandiyah, S., Kehamilan, Persalinan \& Gangguan Kehamilan.Yogyakarta: Nuha Medika.2009

13. Bobak I. M., Lowdermik, D. L., Jensen M. G., Perry, S.EBuku Ajar Keperawatan Maternitas. Edisi Ke - 4. Jakarta: EGC. 2004

14. Eka Puspita S., Kurnia Dwi R.Asuhan kebidanan pada persalinan Cetakan I Jakarta: Trans Info Medika. 2014.

15. Eka Sriwahyuni, Barus, A., Sinambela, M.Pengaruh Teknik Relaksasi Hypnobirthing terhadap Penurunan Rasa Nyeri Kala I Persalinan Normal pada Primipara di Rumah Sehat Kasih Bunda Kec. Medan Selayang J. penelitian Kebidanan dan Kespro. http://ejournal.delihusada.ac.id/index.php/ JPK2R.Vol. 2, No. 1. Oktober2019.

16. Lucky, V. Apa itu Hypnobirthing, TataCara dan Manfaatnya.https://www.motherandbaby.co.id/ article/2019/4/5/12048/Apa-Itu-HypnobirthingIni-Tata-Cara-dan-Manfaatnya, 2019.

17. Nila Qurniasih, Asri Hidayat, D.Faktor-faktor yang berpengaruh terhadap intensitas nyeri persalinan kala I fase aktif di Puskesmas Kota Yogyakarta, 2016.

18. Nicholas, F.H., Humenick, S. hildbirth Education; Practice, Research and Thseory, Philadepia: WB. Saunders Company. 2000.

19. Ratih Prananingrum, Pengaruh Penerapan Hypnobirthing Terhadap Nyeri, penerbitpustakagraha. 2015. 